\title{
Benign Sertoli Cell Tumor
}

National Cancer Institute

\section{Source}

National Cancer Institute. Benign Sertoli Cell Tumor. NCI Thesaurus. Code C67012.

A Sertoli cell tumor of the testis or the ovary which remains localized and does not metastasize to another anatomic site. 